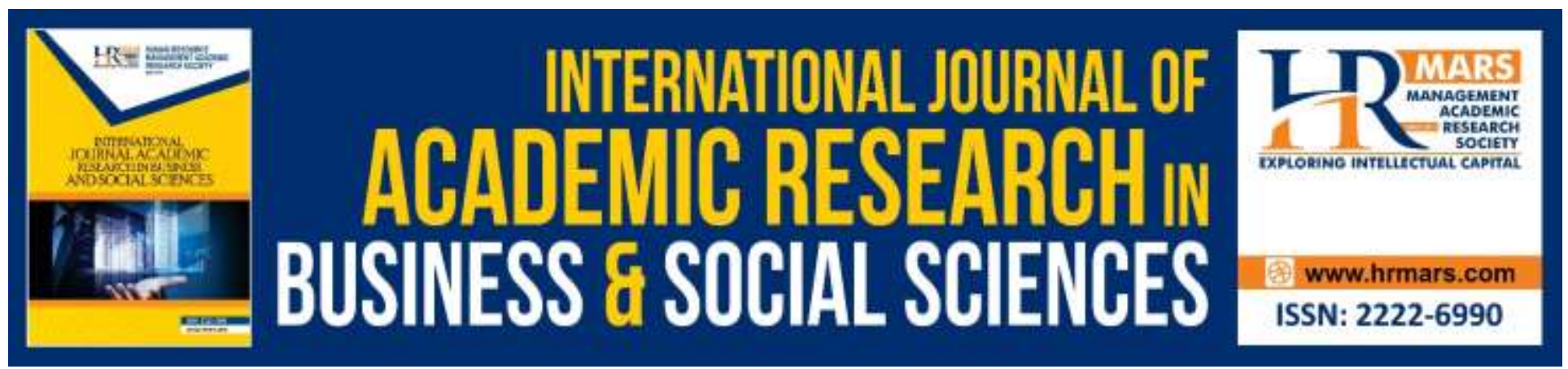

\title{
A Proposed List of Secondary School Teachers' Competencies to Discover and Develop the Multiple Intelligences of their Class Students
}

Alaa' Shdefat, Nashaat Baioumy \& Abdul Hakim Bin Abdullah

To Link this Article: http://dx.doi.org/10.6007/IJARBSS/v10-i2/6933

DOI:10.6007/IJARBSS/v10-i2/6933

Received: 03 January 2020, Revised: 28 January 2020, Accepted: 02 February 2020

Published Online: 22 February 2020

In-Text Citation: (Shdefat et al., 2020)

To Cite this Article: Shdefat, A., Baioumy, N., \& Abdullah, A. H. Bin. (2020). A Proposed List of Secondary School Teachers' Competencies to Discover and Develop the Multiple Intelligences of their Class Students. International Journal of Academic Research in Business and Social Sciences, 10(2), 323-345.

\section{Copyright: (c) 2020 The Author(s)}

Published by Human Resource Management Academic Research Society (www.hrmars.com)

This article is published under the Creative Commons Attribution (CC BY 4.0) license. Anyone may reproduce, distribute, translate and create derivative works of this article (for both commercial and non-commercial purposes), subject to full attribution to the original publication and authors. The full terms of this license may be seen

at: http://creativecommons.org/licences/by/4.0/legalcode

Vol. 10, No. 2, 2020, Pg. 323 - 345

http://hrmars.com/index.php/pages/detail/IJARBSS

JOURNAL HOMEPAGE

Full Terms \& Conditions of access and use can be found at http://hrmars.com/index.php/pages/detail/publication-ethics 


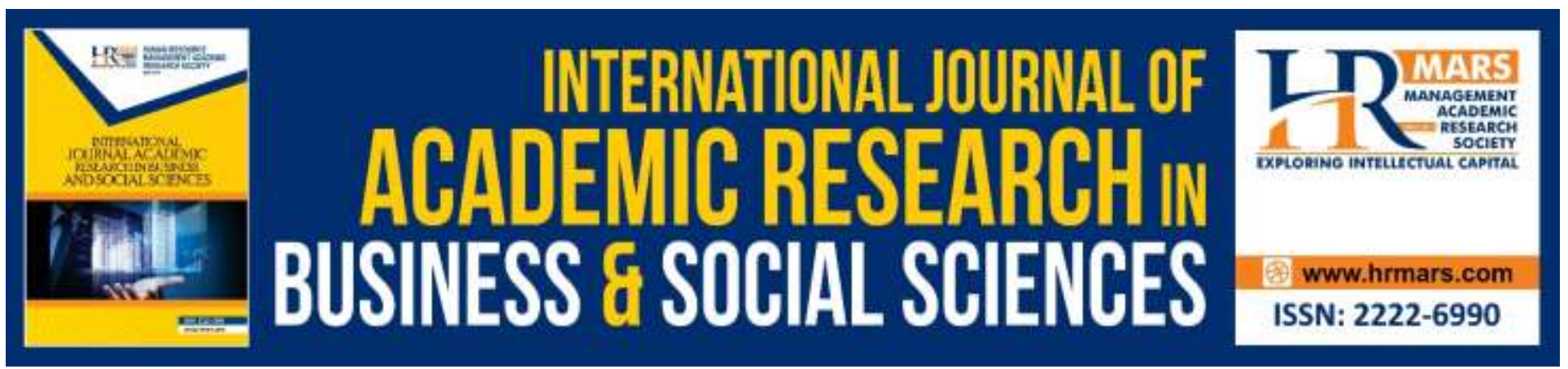

\title{
A Proposed List of Secondary School Teachers' Competencies to Discover and Develop the Multiple Intelligences of their Class Students
}

\author{
Alaa' Shdefat, Nashaat Baioumy, \& Abdul Hakim Bin Abdullah
}

Faculty of Islamic Contemporary Studies, University Sultan Zainal Abidin, Terengganu, MALAYSIA

\begin{abstract}
The intelligence's found in high school students are many, but we rarely find a teacher has all the necessary competencies in dealing with such diverse intelligence's and to identify, develop, and enrich, and straightened it, This study aimed to build a arbitrative list of secondary school teachers necessary qualifications to deal with multiple intelligence's among their students in Mafraq - Jordan schools, to achieve the objective of the study we relied on descriptive analytical method in reference to literature and researches on multiple intelligences, methods of measurement, development and enrichment, The list was made in its initial form then presented to a variety of experts and specialists, and adjustments was made in the light of their opinions and guidance, it was finalized in light of the proportion of acceptable agreement to the arbitrators' views. The study reached a final list of required competencies for teachers to deal with multiple intelligences among their students, the study reached a final list of competencies necessary for teachers to deal with several intelligences among their students, namely: linguistic intelligence, mathematical intelligence, social intelligence in dealing with the identification, development and enrichment, and evaluation of it. The study also recommended the need to hold training courses for teachers to develop those competencies to be an essential component of their goals and their teaching performance within the classroom.
\end{abstract}

Keywords: Teacher Competencies, Multiple Intelligences, High School Students

\section{Introduction}

The educational process seeks to provide appropriate ways to help the teacher deliver information to the students to achieve their goals, and then the teacher is able to build new generations able to keep up with and assimilate the information produced by the world, and bring about change in human behavior. As the educated person who has completed university study is different from the one who did not in his style, work, habits, values, principles and outlook on the various life developments and issues (Gaoqao, 2016) 
INTERNATIONAL JOURNAL OF ACADEMIC RESEARCH IN BUSINESS AND SOCIAL SCIENCES Vol. 10, No. 2, Feb, 2020, E-ISSN: 2222-6990 @ 2020 HRMARS

The educational outlook is transformed nowadays into the individual intelligence rather than the unified intelligence, because individual intelligence depends on the mental skills that can be developed and mastered through proper training. Scientific and educational studies have proved at through the brain anatomy in determining the basic functions of the right and left side of it, that the brain is self-adjusting through its interaction with the influencing environment, develops and grows according to the influential interactions that are based on the responses stemming from environmental changes. Thus, the concept of intelligence has been developed to be a dynamic energy responds to the changes in the environment after being a fixed, inherited, general ability (Afaneh, 2004).

The work nature as a teacher in the school, dealing with groups of students differentiated from each other in their nature and the degree of growth they reached in every aspect of their personality. One of the most important aspects is the mental aspect of differences between students in intelligence and mental abilities. What also is noticeable is the difference in students' ability to cope with different learning situations and their coping with the problems they face within the classroom (Wagih, 1985). The difference between them through the framework of this diversity requires the teacher to work on find the good ways to identify the most developed intelligent types in students by observing and controlling their work within the classroom (giving the freedom to move in the classroom), where some of the intelligences types will appear automatically, Student with linguistic intelligence will speak outside his role, the student with spatial intelligence will take a daydream, and student with a tendency for interpersonal relationships will meet with others. The teacher has to guess most of students' intelligent types by leaving them the free to act where this gives the teacher an opportunity to explore how students need to learn. The another indicator to monitor students' tendencies towards showing multiple intelligences is how do they spend their free time in school, in other words, what activities are selected by students at school? (Armstrong, 2006).

Teacher's pre-service and in-service training helps in the success of professional growth and scientific advancement. This process helps to raise their competence and equip them with the scientific, educational and professional skills and culture required by the nature of their work which will contribute to raising their productivity. There is many justification for the professional growth of the teacher, including: information explosion and the resulting rapid change and expansion of knowledge, accelerated technical development, the development of the concept of education from a narrow concept focuses on the mental aspect to a wide one covering the various aspects of the student personality, the emergence of global concepts such as globalization and quality, and the ease of information flow thanks to the development of multiple communication channels so that the teachers cannot remain isolated from scientific and technical development, Hence, the professional growth is a prerequisite for their success in carrying out the renewed and evolving tasks in their work. Continuing educational training is the appropriate way of sustaining this growth (Sneineh, 2014).

In 1983, Howard Gardner authored a book (Frames of mind) where he concluded that there are seven basic intelligences in humans: (linguistic intelligence, mathematical logic, spatial intelligence, motor physical intelligence, musical intelligence, social intelligence, and personal intelligence.) (Jaber, 2003).

The theory of multiple intelligences of the American scientist Gardner is one of the leading theories in the field of intelligence and its ability to detect and measure the mental abilities of the individual, the theory contributed in monitoring the modality of the emergence of the abilities and 
methods of knowledge acquisition. The book (Frames of mind) which was published in 1983 refuted the idea that intelligence is linked to heredity as well as the idea of intelligence measuring, and called for the existence of multiple types of intelligence filled in the human brain (Nofal, 2007). The theory is one of the useful theories in the cognition of learning and teaching methods because it detects the strengths and weaknesses of the learner. As each individual is distinct from others, where intelligence differs from person to person, highlighting the true meaning of individual differences between people and the unique character of one person (Alufi, 2014). The theory is derived from Gardner's observations of individuals who have high mental abilities but do not get high marks in intelligence tests where their grades varies form intermediate to low, drawing Gardner's attention to the fact that intelligence consists of multiple intelligences and each intelligence works independently which are : Verbal logical intelligence, mathematical logical intelligence, spatial intelligence, motor physical intelligence, musical intelligence, interpersonal intelligence, and personal intelligence (Gardner, 1983).

\section{The study Problem}

The teacher is the focus of the teaching process in all its situations where he is required to meet the needs of his students in the secondary stage and the problems they face, as they need a continuous educational guidance and care, and to identify the difficulties and problems they face in their academic and social life in order to reach mature solutions that work on reducing those difficulties and problems (Issawi, 2000).

Teachers are able to grow professionally by doing the teaching process and exposure to multiple pedagogical experiences when they give students lessons in classrooms. However, they need many creative teaching skills to meet the challenges and problems they face because of technological development, especially at the beginning of their professional practice. Although there are disparities in the performance of teachers, most of them use the basic teaching styles which rely on the preservation and indoctrination of the textbook without any additions or creations or innovations, so that the student who has multiple intelligences will be marginalized.

Therefore, the problem of the study was determined that there is a weakness in the competencies of teachers in the secondary stage to deal with the multiple intelligences of their students, which led to the weakness of the level of students, which may be caused by the lack of these competencies; therefore the study aimed to build an arbitrator list for the needed qualifications of secondary school teachers qualify them to deal with the multiple intelligences of their students in the schools of the governorate of Mafraq - Jordan, which will reflect positively on the development of students' intelligence in all areas of life.

\section{Study Questions}

The main question:

What are the competencies needed for secondary school teachers to deal with the multiple intelligences of their students from the perspective of specialists?

Several questions arise from this question:

A- What are the general competencies required for secondary school teachers in dealing with the multiple intelligences of their students from the point of view of specialists? 
INTERNATIONAL JOURNAL OF ACADEMIC RESEARCH IN BUSINESS AND SOCIAL SCIENCES

Vol. 10, No. 2, Feb, 2020, E-ISSN: 2222-6990 @ 2020 HRMARS

B- What are the general competencies required for secondary school teachers in dealing with the linguistic intelligence of their students from the point of view of specialists?

C- What are the general competencies required for secondary school teachers in dealing with the social intelligence of their students from the perspective of specialists?

D- What are the general competencies required for secondary school teachers in dealing with the mathematical intelligence of their students from the point of view of specialists?

\section{Objectives of the Study}

The present study aims to:

A - Identify the general competencies necessary for teachers to deal with multiple intelligences from the point of view of specialists.

B - Identify the competencies necessary for teachers in dealing with linguistic intelligence from the point of view of specialists.

C - Identify the competencies necessary for teachers in dealing with social intelligence from the point of view of specialists.

D - Identify the competencies necessary for teachers in dealing with mathematical intelligence from the point of view of specialists.

\section{The Importance of Study}

1- Contribute in providing the Ministry of Education and universities with a list contributes in to raising the competencies of teachers to deal with the multiple intelligences of their students.

2- Help teachers to recognize and develop, enrich and evaluate multiple intelligences.

\section{Definitions}

- Intelligence: The ability to provide meaningful behavior and logical thinking and to deal effectively with the surrounding environment (Khalidi, 2001).

- Multiple intelligences: Human nature has eight differentiated units of mental functions, these units are called "intelligences", where they have their own sets of strategies that can be observed and measured. These distinct verbal intelligences are: linguistic intelligence, interpersonal intelligence, spatial intelligence, Musical intelligence, physical motor intelligence, logical mathematical intelligence, personal implicit intelligence, and natural intelligence (Ahdal, 2009).

- The theory of multiple intelligences: a model that describes how individuals use their multiple intelligence to solve a problem, and focus on the mind processes of addressing the content of the situation before it Reach the appropriate solution (Al-Ahdal, 2009).

- Competencies: The ability to use the appropriate methods and ways to help achieving the desired high level learning goals. (Kunduz and Sheikha, 2011), as the "Encyclopedic Dictionary of Education and Training" defines the competence by the positive property of the individual, which attests to his ability to accomplish certain tasks (Mohammad \& Mohammed, 2009).

- Linguistic intelligence: The ability to effectively use words orally (as in the case of a judge, a preacher or a politician) or editing (such as a poet). This intelligence includes the ability to deal with and address the language construction, voices and meanings. (Jaber, 2003). 
- Logical mathematical intelligence: It is the ability of the individual to use numbers such as (mathematicians, accountants and statisticians) and to well induce such as in (scientists and programmers). (Mohammad Omran, 2009).

- Social intelligence: the ability to recognize others' moods, goals, motivations and feelings, distinguishing between them includes sensibility to facial expression, sound and gestures. (Jaber, 2003).

\section{Methodology of the Study}

Teacher competencies

The idea of (competence) appears in Rooney Amgis's theory in 1909, with the Generative grammar of Chomsky. The term "competence" can be defined as: firstly ability of producing and understanding an infinite number of sentences secondly as: linguistics trait (2001, Romainville, et all).

Competence, in the view of "Romanville" means the ability to integrate career skills, mastery, good presence with others as well as good planning for the future, competence enable the individual in different situations to adapt, and solve the problems facing him, enabling him to complete the work in the future. (2001, Romainville, et all).

The study will address in details to the competencies of secondary school teachers required to deal with the multiple intelligences of their students, as follows:

\section{Identification Competencies}

Where all teachers must start their teaching work by identifying the intelligence of their students, through the following procedures:

1- Observation: Accurate observation of students in their normal lives is one of the most important ways to discover their multiple intelligences, where the most important things must be observed in the student is:

A. Observing the intelligence used by the student in learning any subject or dealing with experience in the classroom or outside.

B. Observing the student's performance or the results of his learning in any program of activity or any content presented to him during the course of the practice, or his problem-solving behavior

C. Observing the way that student's is dealing with knowledge, knowledge, storage and comprehension.

D. The way students interact with different daily events and stimulus.

E. E. Students 'reports about themselves or others' reports about them, such as teacher reports, activities supervisor, parents, and classmates.

F. Use of psychological measures such as: (intelligence tests, academic achievement, and measurement of creativity).

G. Indicators lists of intelligence: There are many lists of intelligences, which represent the basic indicators of each intelligence, such as the list of Linda Campbell, Thomas Armstrong and other lists (Nafin Salah, 2010). 
INTERNATIONAL JOURNAL OF ACADEMIC RESEARCH IN BUSINESS AND SOCIAL SCIENCES Vol. 10, No. 2, Feb, 2020, E-ISSN: 2222-6990 @ 2020 HRMARS

\section{Development Competencies}

Development in language means the growth and increase, and as a term means a rapid and cumulative increase in time. Hence, the procedural definition of development in the current study is: the teacher's actions, methods and activities used to increase the acquisition of multiple intelligences among students in general and linguistic, social and Mathematical intelligences in particular (Arabic Language Complex, 2004).

Jabir (2003) emphasizes on the need to pay attention to and take into account individual differences among students to maintain their intelligence level. Because he was aware that the person with weak intelligence if he was provided a healthy environment to develop this intelligence it may become strong, as well as with the person with high intelligence if he deprived of the environmental conditions supporting the intelligence which may decrease his level of intelligence. The process of developing students' intelligence includes defining their objectives, elements, methods and steps where the teacher develops these intelligences, and implements the various instructional strategies with his students and tries to achieve his chosen educational goals by focusing on the important skills that must be teach to his students to help them develop their intelligence, namely:

1- 1 - The skill of searching and inspection by encouraging the student to search for information to answer the question posed to them.

2- The skill of conclusion, by developing the ability to find new information from available information.

3- The skill of comparison, by training the student to find similarities and differences between two or more concepts after explanation and description.

4- The skill of analysis, in which the teacher trains the student to divide the items main points into important small parts then describe each and then present the conclusion.

5- Ranking and classification skills based on a particular criterion, where concepts and events are arranged based on this criterion.

6- The skill of decision - making, by identifying the details of the subject, and assessing the advantages and disadvantages of it, in order to reach the best choice.

Research has shown that intelligence is not a fixed amount since childhood. It could be developed for adults and young people through the attitudes of the human being in dealing with life situation that helps to nourish the mind and improve its abilities, which also could be done through reading ordinary books or electronic, by reading subjects which are rich in knowledge (Stillman, 2018).

\section{Some of the ways that Contribute to the Development of Intelligences}

1- Language enrichment: Language occupies an important place in increasing the development of people's thinking. Studies have shown that people who have developed in a linguistically rich environment enjoy a certain amount of intellectual intelligence. Individuals who lack this can also be compensated it through the effort to study and read in order to enrich their own language in addition to the importance of keeping a dictionary continuously; to use when passing through new or unfamiliar words. (Cassidy ،2018). 
2- $\quad$ Brain exercises: the brain, like many parts of the human body, needs regular exercise in order to maintain strength and vitality. Some more common brain strengthening exercises include fun activities like crossword puzzles, Sudoku, and other word- and number-based brain teasers. Or by simply mixing up the routine by brushing teeth with the opposite hand or walking a different way to work forces brain to work harder than usual.

\section{Competencies of Enrichment}

Is to give learners more diverse and advanced experiences, by studying some topics more broadly and solving some problems (Rahman, 1991). where some define it as inserting of amendments or additions to the curricula prescribed for ordinary students to fit with the outstanding students in the areas of cognitive, emotional and psychological mobility.

The teacher who contributes to the enrichment process must identify several factors, the most important are:

1- All students should realize that individual learning is indispensable and that each one has the right to study and achieve according to his abilities and competence.

2- The enrichment process does not mean increasing or doubling the number of routine operations and exercises

3- The teacher must do everything in his power to create a conducive atmosphere leads all students in the classroom to respect the mental diversity, diligence and expression of real mental abilities (Rahman and description, 1998).

\section{Assessment Competencies}

Assessment is an important educational necessity as well as an effective tool for judging students' progress, curricula, and educational programs by directly collecting data and information for assessment (Nitko, 1996) Gardner has argued about assessment should promote public understanding of learning goals relevant to students' current and future lives. And Assessment methods should be designed to facilitate students 'achievement of their learning goals, also promoted the active engagement of students in their learning and its assessment where it should be a part of a process of teaching that enables students to understand the aims of their learning and how the quality of their achievement will be judged also to enable and motivate students to show what they can do.

Gardner also emphasizes the importance of self-assessment because it is the important source of information that leads to the selection of appropriate decisions for student learning and achievement. where it should meet standards that reflect a broad consensus on quality at all levels from classroom practice to national policy. (Gardner et al., 2008) the aim of the assessment shouldn't only to identify Students intelligences but the suitable way to assess them and to encourage their other intelligences and to focus on what activates loved by students (Weiss,1999,). Gardner believes that multiple intelligences Assessment should focus on students' performance by giving them a range of activities and tasks, as well as do a lot of interviews because they contribute widely in performance, writing, drawing and other forms of expression that allow them to show what they have. (Stanfor, 2003)

Gardner's assessment of student performance in the field must include the measurement and evaluation process that: 
1 - Differentiate between students and their abilities in these intelligences

2 - Focus on the observation of actual skills and people notes.

3 - Not focusing only on verbal methods in the of intelligences types

4- Diversification of evaluation methods. (Shearer, 1996).

\section{The Theory of Multiple Intelligences}

The theory of multiple intelligences has a great contribution to education. It has shown that teachers need to use many of the tools and materials in implementing strategies in all fields of knowledge and use the multiple intelligences theory to organize and develop innovations that would have been forgotten in the prevailing way of learning. This will be an addition to school curricula to enrich the minds of students who follow their education in school (Armstrong, 1994).

Howard Gardner developed the theory to enable teachers to find ways to help students to master curricula and to create an attractive classroom environment that includes activities and assessment tools that respond to multiple intelligence patterns (Sawsan, 2006).

Multiple intelligences are a biological potential that is a product of the interaction between the formative factors and the environmental factors. People differ in how much intelligence they are born in, their nature and how their intelligence grows. Most people use the combination of intelligences to solve various problems they face, Gardner presented his way to map out the abilities of people by combining these abilities into a set of intelligences. Al-Khafaf (2013). The following is an overview of the intelligences in the current study:

\section{Linguistic / verbal Intelligence}

Is the ability to manipulate the alphabets of the language: the ability to merge and synthesize between these letters in order to form words and sentences. The level of your linguistic or verbal intelligence is often measured by the size and amount of words you use. And your ability to see the different relationships between these words (Bozan, 2007).

\section{Logical Mathematical Intelligence}

Its includes the ability to use numbers and effective reasoning, as well as includes sensitivity to patterns, relationships, logical and abstract issues, the ability to think logically, uses numbers effectively, and deals with problems scientifically, and this intelligence uses sensitivity to models and logical relationships in the reporting and theoretical activities. And those who have this kind of intelligence have a good sense of the cause and effect of those in their age (Ward Abdelkader, 2013).

Gardner has proposed a model of cognitive growth that evolves from kinetic activities to basic processes that may depict growth in one of the mathematical logical intelligence specialization, which refers to the individual ability to abstractive, deductive and conceptual think, to use numbers effectively and to perceive relationships, to discover logical and numerical patterns, where he can do good reasoning such as the mathematician and computer programmer, and this intelligence includes sensitivity to models, logical patterns, relationships, issues, functions and other abstractions that are associated with them, and types of processes used in the service of logical and mathematical intelligence, which includes: categories classification, conclusion, and generalization , arithmetic, hypotheses testing. (Nelson, 1998). 


\section{Social Intelligence}

In 1925, Thorndike defined social intelligence as "the ability to understand, control, and manage men and women, boys and girls, so that they perform wisely in human relations." (Abu Hatab, 1996) This is the first definition that accurately distinguishes social intelligence; it is used to this day, because it is relevant to daily reality (Selami, 2000).

Guilford (1965) defined social intelligence as "the ability to understand the thoughts, feelings, goals, and psychological state of others." Weinstein (1969) also defined social intelligence as "the ability to adapt to the functions of social relations with others" (Hassan, 2003).

Zahran (2000) identified social intelligence as: the ability to understand people and social relationships, interact with others, behave appropriately in situations, and the control of behavior and social relationships, leading to social harmony, and the success of the individual in his social daily life.

In the definition of social intelligence, Abu Hammad adds that the ability to understand the feelings, motivations, moods, goals and interests of others and differentiate between them, in addition to the sensitivity of individuals to facial expression, gestures and voice, and the ability to communicate, interact and respond to them (Abu Hammad, 2007).

Gardner has defined social intelligence as: the ability of the individual to understand the motivations and desires of individuals and others and then works effectively with others, and salesmen and teachers, religious and political leaders are characterized by this type of intelligence and other members of society. (Gardner, 2005). Learners who have social intelligence may find their way into group work and have the ability to participate in the role of leadership and negotiation as well as to communicate with others (Gardner, 1993).

\section{The Limits of the Study}

1- Objective limit: To build a list of the competencies of the secondary school teachers required to deal with their students' linguistic, mathematical and social intelligence (general competencies, Identification, Development, Enrichment, Assessment ).

2- Human limit: psychological counseling, curriculum, education, Assessment and evaluation specialists.

1. Time limit: The study was conducted for the first semester of the academic year (2019)

2. Spatial limit: Allocations in Jordanian Universities and Saudi Universities.

\section{The Study Community}

Psychological counseling, curriculum, education, Assessment and evaluation Specialists at the Jordanian universities in Mafraq.

The study sample:

A number of ten psychological counseling, curriculum, education, Assessment and evaluation Specialists.

\section{Study Tool}

Arbitration of the qualification of secondary school teachers to deal with the multiple intelligences of their students. 
INTERNATIONAL JOURNAL OF ACADEMIC RESEARCH IN BUSINESS AND SOCIAL SCIENCES Vol. 10, No. 2, Feb, 2020, E-ISSN: 2222-6990 @ 2020 HRMARS

\section{Previous Studies on Multiple Intelligences}

The researcher did not find in the limits of his knowledge studies of the competencies of secondary school teachers required to deal with the multiple intelligences of their students in Jordan, where he took a previous studies related most closely to the current study, and the following is a chronological sequence of according to the view of those studies descending order oldest to newest:

The study of Qajeh and Skeirava (2011). on the "difficulties faced by teachers in teaching competencies" aimed at learning the degree of difficulties experienced by teachers in teaching competencies, by answering the following question: What degree of difficulties teachers face The study sample consisted of 74 teachers randomly selected during the academic year 2010/2011. The two researchers built a questionnaire that included 25 items distributed over three elements. The results of the study revealed that the degree of difficulties faced by teachers in teaching competencies is medium, with an average of 1.85 .

The study of Al-Majawi, Al-Qallaf and Al-Eneizi (2011) the appropriateness of teacher preparation programs for educational quality requirements of educational quality in the 21st century of the Faculty of Basic Education in the State of Kuwait. The researcher conducted a questionnaire consisting of (35) built on Five-point scale, distributed to (60) members of the faculty with the percentage of $80 \%$ of the total members to express their Suggestion. The results of the study came as following:

A - The programs of the current methods of teaching are lacking in the modern method based on scientific thinking and problem solving methods.

B - The teacher training program for learners needs some international culture to understand international affairs.

C- Teacher preparation programs need special curricula to educate students about their rights and duties.

D- Experts and faculty members also suggest that the programs should take into account the normative levels of access to educational quality in education.

E- Using international expertise in the field of modern technology to spread and activate modern teaching methods, while paying attention to the physical structure of school facilities.

Ryan (2013). conducted a study entitled by "Patterns of multiple intelligences among high school students in the Directorate of Hebron Education in Palestine". The study aimed to these intelligences according to the variables of gender, grade, academic track, and achievement level in mathematics. In order to achieve these objectives, the study tool was applied after it was verified validity and stability on a sample of (609) students who were selected in a cluster-class manner from all secondary school students in the Hebron Education Directorate. The results of the study showed that the common intelligences of the students were social, personal, verbal, physical, musical, mathematical, spatial, and natural there were statistically significant differences in verbal and musical intelligence according to the gender variable in favor for females In physical and physical intelligence in favor of males, and according to the variable of the class in multiple intelligences as a whole and in verbal, visual, physical, social, and natural intelligence for 11th graders, and according to the variable of the academic path in multiple intelligences as a whole and in verbal, logical, , Physical and personal for students of the scientific track, and according to the variable level of achievement in mathematics in multiple intelligences as a whole. And in both verbal, visual and personal intelligence for those with a high level of achievement, and logical intelligence for students with high and average achievement. 
INTERNATIONAL JOURNAL OF ACADEMIC RESEARCH IN BUSINESS AND SOCIAL SCIENCES Vol. 10, No. 2, Feb, 2020, E-ISSN: 2222-6990 (C) 2020 HRMARS

Al-Sarayreh (2008). conducted a study entitled "The grades of teacher's contribution in the development of multiple intelligence in secondary school students." The study aimed at investigating the contribution of teachers in the development of multiple intelligence among students in secondary schools and finding individual differences according to the variables, and a random sample of (201) teachers and teachers from the teachers off al-Karak schools during the second semester of the academic year 2005/2006 to identify the contribution of them in the development of multiple intelligence in secondary school students. The researcher designed a questionnaire consisting of (36) paragraphs distributed on seven types of intelligence, and extracted the psychometric characteristics of it. The results showed the contribution of teachers in the development of multiple intelligence is high, and there is no difference in the degree of contribution attributed to scientific qualifications, with differences due to experience and specialization.

\section{Steps to Prepare list Paragraphs before Arbitration}

A. Determine the purpose of setting up the list.

B. Refer to previous studies and literature on multiple intelligences, and competences of teachers

$\mathrm{C}$ - The excogitation of the list and preparing its initial form.

Table of components of the list paragraphs before arbitration

\begin{tabular}{|c|c|c|c|c|}
\hline NO & Field & \multicolumn{2}{|c|}{ Competences } & $\begin{array}{ll}\text { Number } & \text { of } \\
\text { paragraphs }\end{array}$ \\
\hline 1 & General competences & General & General & 16 \\
\hline \multirow[t]{4}{*}{2} & \multirow{4}{*}{ Linguistic intelligence } & \multirow{4}{*}{ Special } & Identification & 18 \\
\hline & & & Development & 9 \\
\hline & & & Enrichment & 10 \\
\hline & & & Assessment & 5 \\
\hline \multirow[t]{4}{*}{3} & \multirow{4}{*}{ Social intelligence } & \multirow{4}{*}{ Special } & Identification & 11 \\
\hline & & & Development & 8 \\
\hline & & & Enrichment & 7 \\
\hline & & & Assessment & 5 \\
\hline \multirow[t]{4}{*}{4} & \multirow{4}{*}{$\begin{array}{l}\text { Mathematical } \\
\text { intelligence }\end{array}$} & \multirow{4}{*}{ Special } & Identification & 11 \\
\hline & & & Development & 5 \\
\hline & & & Enrichment & 5 \\
\hline & & & Assessment & 5 \\
\hline
\end{tabular}


INTERNATIONAL JOURNAL OF ACADEMIC RESEARCH IN BUSINESS AND SOCIAL SCIENCES Vol. 10, No. 2, Feb, 2020, E-ISSN: 2222-6990 ¿ 2020 HRMARS

Table of distribution of the specialties of the 10 arbitrators divided into two countries, Jordan and Saudi Arabia

\begin{tabular}{|c|l|l|}
\hline NO & \multicolumn{1}{|c|}{ The Specialization } & \multicolumn{1}{|c|}{ The number } \\
\hline 1 & Psychological Counseling and Educational Psychology & 3 \\
\hline 2 & Assessment and Evaluation & 2 \\
\hline 3 & Education and curriculum & 2 \\
\hline 4 & Educational psychology & 3 \\
\hline
\end{tabular}

Table of Statistical results of the analysis of the proportion of agreement of arbitrators' responses to the preliminary list

\begin{tabular}{|c|c|c|c|c|c|}
\hline NO & \multicolumn{2}{|l|}{ Intelligence } & Competences & \multicolumn{2}{|c|}{ Indicators } \\
\hline 1 & $\begin{array}{l}\text { Must be available in } \\
\text { teachers }\end{array}$ & $\begin{array}{l}\text { Gener } \\
\text { al }\end{array}$ & General & $85 \%$ & $15 \%$ \\
\hline \multirow{4}{*}{2} & \multirow{4}{*}{ Linguistic intelligence } & \multirow{4}{*}{ Special } & Identification & $80 \%$ & $20 \%$ \\
\hline & & & Development & $90 \%$ & $10 \%$ \\
\hline & & & Enrichment & $90 \%$ & $10 \%$ \\
\hline & & & Assessment & $95 \%$ & $5 \%$ \\
\hline \multirow{4}{*}{3} & \multirow{4}{*}{ Social intelligence } & \multirow{4}{*}{ Special } & Identification & $80 \%$ & $20 \%$ \\
\hline & & & Development & $90 \%$ & $10 \%$ \\
\hline & & & Enrichment & $90 \%$ & $10 \%$ \\
\hline & & & Assessment & $95 \%$ & $5 \%$ \\
\hline \multirow{4}{*}{4} & \multirow{4}{*}{ Mathematical intelligence } & \multirow{4}{*}{ Special } & Identification & $80 \%$ & $20 \%$ \\
\hline & & & Development & $90 \%$ & $10 \%$ \\
\hline & & & Enrichment & $90 \%$ & $10 \%$ \\
\hline & & & Assessment & $95 \%$ & $5 \%$ \\
\hline
\end{tabular}

\section{Tool Validation}

The researcher verified the validity of the content of the scale by presenting the scale to (10) arbitrators of psychological counseling, curriculum, education, Assessment and evaluation Specialists in Jordanian and Saudi universities to review in terms of paragraphs language as shown in Appendix $A$, clarity of the meaning, the relevance of the paragraphs to the scale to which they belong, and their relevance to the Secondary School Students environment. And the amendment of some paragraphs that were agreed between the arbitrators by $(90 \%)$, So that the number of paragraphs of the scale in 
INTERNATIONAL JOURNAL OF ACADEMIC RESEARCH IN BUSINESS AND SOCIAL SCIENCES

Vol. 10, No. 2, Feb, 2020, E-ISSN: 2222-6990 ¿ 2020 HRMARS

its final form became (110) which has been divided into three intelligences, indicating the apparent truthfulness of all sub-dimensions and scale as a whole (see Annex 1,2,3,4).

\section{Study Results}

To answer the main question: What are the competencies needed for secondary school teachers to deal with the multiple intelligences of their students from the perspective of specialists? Several questions stem from this question

A-What are the general competencies necessary for teachers in dealing with multiple intelligences from the perspective of specialists?

-The researcher studied the previous studies and researches including: Amani Mahmoud and Lina AlMahama (2014) (2008), A Study of the Life of Al-Majawi, Al-Qallaf and Al-Enezi (2011)

-The theoretical framework of the study

- He made a list of Teachers competencies consists of four main areas: general competencies, the competencies of linguistic intelligence, the competencies of social intelligence, the competencies of mathematical intelligence. Where the list was presented to the arbitrators, adjustments has been made to the competencies of teachers, and output them as final. (Annex 1,2,3,4)

B - What competencies necessary for teachers in dealing with linguistic intelligence?

- Review previous studies related to linguistic intelligence

- The theoretical framework of the study

- A list of the competencies of teachers on linguistic intelligence. The list was presented to the arbitrators, adjustments has been made to the competencies of teachers, and output them as final. (Annex 2)

$\mathrm{C}$ - What competencies necessary for teachers in dealing with social intelligence? Review previous studies related to linguistic intelligence

- The theoretical framework of the study

- A list of the competencies of teachers on linguistic intelligence. The list was presented to the arbitrators, adjustments has been made to the competencies of teachers, and output them as final. (Annex 3)

D- What are the necessary competencies for teachers in dealing with mathematical intelligence? Review previous studies related to linguistic intelligence

- The theoretical framework of the study

- A list of the competencies of teachers on linguistic intelligence. The list was presented to the arbitrators, adjustments has been made to the competencies of teachers, and output them as final. (Annex 3)

\section{Study Recommendations}

1- the need to benefit from the list of qualifications of teachers necessary to develop the intelligence of students of secondary school.

2- Identify the skills owned by students and how to develop, enrich and assessment

3- help teachers to recognize the competencies that contribute to raise their level within the classroom 
INTERNATIONAL JOURNAL OF ACADEMIC RESEARCH IN BUSINESS AND SOCIAL SCIENCES Vol. 10, No. 2, Feb, 2020, E-ISSN: 2222-6990 ¿ 2020 HRMARS

4-Conducting the continuous development to the measurement of multiple intelligences, research and re-evaluation and development annually to keep up with local and global developments in various fields.

5-Raising the competencies of teachers in the development of students' intelligence in the Hashemite Kingdom of Jordan.

6-Donig further studies to determine the reality of secondary Teachers Competencies to deal with the multiple intelligences of their students.

\section{Study Suggestions}

1- Prepare a tool to raise the competencies of teachers in dealing with the intelligence of students in the secondary stage, and other stages.

2- A preparation of a study to identify the reality of the efficiency of secondary school teachers required to deal with the multiple intelligences of their students.

3 - Holding training courses for teachers; to develop those competencies they have to be an essential component of their goals and their performance in the classroom.

\section{Conclusion}

The study reached a final list of required competencies for teachers to deal with multiple intelligences among their students, the study reached a final list of competencies necessary for teachers to deal with several intelligences among their students, namely: linguistic intelligence, mathematical intelligence, social intelligence in dealing with the identification, development and enrichment, and evaluation of it. The study also recommended the need to hold training courses for teachers to develop those competencies to be an essential component of their goals and their teaching performance within the classroom.

\section{References}

Aga, W. (2014). "Personal Intelligence", "Yakut Academy for Development, Creativity and Human Development"

Zahran, H. A. S. (2000). Social Psychology. 6, the world of books.

Selamy, N. (2000). Encyclopedia of Psychology, Part 3, Publications of the Ministry of Culture, Damascus.

Hassan, M. A. (2003). Measurement and evaluation of the capabilities of multiple intelligences. 1, Dar Al-Fikr, Amman

Al-Halaiyi, A. R., Mohammed C. (2016). Journal of "Joomla Diyala" The impact of the use of the strategy of the ring house plan in the achievement and visual intelligence spatial physics students in the second grade intermediate, No. 69, Directorate General of Diyala, Iraq.

Tony, B. (2007) book entitled "The Power of Verbal Intelligence" Jarir Bookstore, Riyadh.

Nchwati, A. M. (1998). book entitled "educational psychology" Amman, Dar al-Furqan.

Mohammed, N. A. (1991). Individual needs of students and mastery of learning, Dar Al-Marikh for publishing, Saudi Arabia.

Al-Faqihi, Abdul Wahid Awlad (2012).

Khalidi, A. (2001) Mental Health, Arab Publishing House, Arab Library, I 
INTERNATIONAL JOURNAL OF ACADEMIC RESEARCH IN BUSINESS AND SOCIAL SCIENCES

Vol. 10, No. 2, Feb, 2020, E-ISSN: 2222-6990 @ 2020 HRMARS

Al-Ahdal, A. Z. (2009). Effectiveness of Teaching Activities Based on the Theory of Multiple Intelligences in Improving the Achievement of Geography and Survival of Learning Effectiveness among First Grade Students in Jeddah, Umm Al-Qura University Journal of Educational and Psychological Sciences.

Abu Hatab, F. (1996). Mental Capacity, I 5, Anglo Egyptian Library, Cairo

Abu Hammad, N. (2007). Intelligence tests and personal measurements. Field application. World Book Wall, Amman, Jordan. World of Modern Books, Irbid - Jordan.

Ezzedine, S., Al-Awaidi. (2006). Methods of Learning for Female Students of the Faculty of Education in Multiple Intelligences in Saudi Arabia, Jeddah, Reading and Knowledge Magazine, Egyptian Society for Reading and Knowledge, Faculty of Education, Ain Shams University, Vol.

Hassan, M. M. (2015). research entitled "intelligence - physical motor and its relationship to thinking schematic in the players advanced football" Faculty of Physical Education and Sports Science / University of Kufa - Baghdad.

Al-Khafaf, I. A. (2013). A book entitled "Emotional Intelligence" Dar Al-Manakh for Publishing and Distribution. Amman, Jordan.

Jabir, J. A. (2003). Multiple Intelligences and Understanding - Development \& Impeding, Arab Thought House, Cairo, i.

Issawi, A. R. M. (2000). childhood and adolescent disorders and treatment, University Library, Beirut.

Ben Gaoqao, R. (2016). The role of teacher and learner according to competency approach "The fourth year of primary education model", Master Thesis, University of Qasdi Marbah Ouargla, Algeria

Afaneh, E. A. N. (2004). Levels of Multiple Intelligence among Students of Basic Education in Gaza and Their Relationship to Achievement in Mathematics and their Attitudes Towards it, Journal of the Islamic University, 12 (2), 366-323

Abu Sneineh, O. (2014). The degree of commitment of teachers of social studies and their teachers in the upper elementary stage to the national standards for the development of teachers professionally from the perspective of their principals in UNRWA schools in Jordan / Al-Najah University Journal of Research (Humanities) Number 4

Hijazi, Y. (2009). Multiple Intelligences and the Reality of the Traditional School, Palestine Counseling Center, Palestine

Al-Alfi, A. (2014), Curriculum of Kindergartens, Al-Rashed Library, Saudi Arabia.

Nofal, M. (2007). Multiple Environments in the theoretical and practical classroom, Dar Al-Masirah, Amman.

Thomas, A. (2006). The Multiple Intelligences in the Classroom, Dar Al-Kitab Al-Tarbawi for Publishing and Distribution, Saudi Arabia.

Mahmoud, I. W. (1985). Consumption Skills. Wise Knowledge Management. Egypt, Cairo.

Arabic Language Complex (2004). Shorouk International Library. Folder (1) Edition (4).

Kunduz, A., Sheikha, M. (2011). Research paper entitled "Means of measuring teaching competencies among teachers" Journal of Educational and Human Sciences. Algeria.

Omran, M. H. (2009). article entitled "Types of multiple intelligences" magazine teacher.

Yamin, W. A. (2013). Mathematical thinking patterns and their relation to multiple intelligences and the desire to specialize and collect the students of the tenth grade in Palestine. Master Degree, National University of Success. 
INTERNATIONAL JOURNAL OF ACADEMIC RESEARCH IN BUSINESS AND SOCIAL SCIENCES

Vol. 10, No. 2, Feb, 2020, E-ISSN: 2222-6990 @ 2020 HRMARS

Nitko, A. (1996). Educational assessment of students (2ed), London: Prentice Hall Inc

Gardner, J., Harlen, W., Hayward, L., \& Stobart, G. (2008). Assessment Reform Group

Stanford, P. (2003). Multiple Intelligences for Every Classroom. Intervention in School \& Clinic- 39 (2).

Weiss, S. (1999). All Kinds of Smarts. Meeting With H. G. NEA

(National Education Association) Today, Washington, Mar 1999

Guilford, J. (1954), Psychometric Methods, McGraw- Hill Psychological testing, History principles and Applications, Allyn \& Bacon, U.S.A.

Armstrong, T. (1994). "multiple Intelligences in the classroom. Virginia, Association for Supervision and Curriculum Development.

Nelson, K. (1998). " Developing Students Multiple Intelligences".New York: holistic

Gardner, H. (1993). Multiple Intelligences. New York, Basic Book.

Bryant. (2010), " Top 5 Ways to Get Smarter " 'www.howstuffworks.com, Retrieved 13-2-2018. Edited.

Sarah Cassidy, "This Is How You Can Raise Your IQ and Improve Your

Memory" ‘www.lifehack.org, Retrieved 13-2-2018. Edited.

Charles, W. B. (2010). "Top 5 Ways to Get Smarter. www.howstuffworks.com, Retrieved 13-2-2018. Edited.

Shearer, B., \& James, J. (1994). The Validation of the Hillside Assessment of Perceived Intelligences (HAPI): A Measure of Howard Gardner's Theory of Multiple Intelligences. Paper presented at the Annual Meeting of the American Educational Research Association (New Orleans, LA, April 4-8) pp.1-20.

Salah, N. A. (2010). Development of Intelligence in Children, 4th edition, Dar Nahdet Misr Publishing, Cairo. 
Annexes

Annex (1)

Teacher's general competencies

\begin{tabular}{|c|c|}
\hline NO & Teacher's general competencies \\
\hline 1 & The concept of multiple intelligences. \\
\hline 2 & Types of Multiple intelligences. \\
\hline 3 & $\begin{array}{l}\text { Identify the theoretical foundations on which the theory of multiple } \\
\text { intelligences is based on. }\end{array}$ \\
\hline 4 & How to deal with the multiple intelligences of his students. \\
\hline 5 & $\begin{array}{l}\text { Recognition of the characteristics of the multiple intelligences of students, } \\
\text { which are attributed to the social, environmental and cultural backgrounds } \\
\text { Identifications. }\end{array}$ \\
\hline 6 & $\begin{array}{l}\text { Appropriate strategies and methods of teaching to suit multiple student } \\
\text { intelligences. }\end{array}$ \\
\hline 7 & $\begin{array}{l}\text { Reminds the appropriate ways to deal with multiple intelligences and } \\
\text { integrates them into classroom lessons. }\end{array}$ \\
\hline 8 & $\begin{array}{l}\text { Explain the appropriate ways to develop multiple intelligences among their } \\
\text { students }\end{array}$ \\
\hline 9 & $\begin{array}{l}\text { Use appropriate methods and activities that contribute to enriching multiple } \\
\text { intelligences. }\end{array}$ \\
\hline 10 & Knowing how to Assess multiple intelligences. \\
\hline 11 & $\begin{array}{l}\text { Recognition of individual differences and inequality of individuals in mental } \\
\text { abilities. }\end{array}$ \\
\hline 12 & $\begin{array}{l}\text { The ability to use some standardized measurements and tests to measure } \\
\text { multiple intelligences. }\end{array}$ \\
\hline
\end{tabular}

Annex (2)

Special competencies must be reached by the teacher

(Linguistic intelligence)

\begin{tabular}{|l|l|}
\hline A & $\begin{array}{l}\text { The identification competencies (linguistic intelligence) The teacher should } \\
\text { distinguish the following linguistic intelligences }\end{array}$ \\
\hline 1 & The student writes better than his age \\
\hline 2 & The student tells stories and jokes \\
\hline 3 & Student has strong memory in names, dates and phrases \\
\hline 4 & Students enjoy playing with words and reading books and stories \\
\hline 5 & Communicates with others in a high verbal and qualitative manner \\
\hline 6 & He has a high listening when reading the lesson \\
\hline 7 & $\begin{array}{l}\text { Student likes to write and search for new vocabulary using the lexicon and the } \\
\text { dictionary }\end{array}$ \\
\hline 8 & Learns other languages easily and quickly \\
\hline
\end{tabular}


INTERNATIONAL JOURNAL OF ACADEMIC RESEARCH IN BUSINESS AND SOCIAL SCIENCES Vol. 10, No. 2, Feb, 2020, E-ISSN: 2222-6990 @ 2020 HRMARS

\begin{tabular}{|c|c|}
\hline 9 & The student shows the ability to spell words accurately and correctly \\
\hline 10 & The student has a good knowledge of linguistic and rhetorical methods. \\
\hline 11 & $\begin{array}{l}\text { The student shows the ability to read events and analyze them in depth and } \\
\text { accurate }\end{array}$ \\
\hline 12 & Student has a good number of words \\
\hline 13 & $\begin{array}{l}\text { The student speaks fluently and with others and able to conduct successful } \\
\text { dialogues }\end{array}$ \\
\hline 14 & Student preserves poetry and deliver them distinctly \\
\hline 15 & Students memorize stories and deliver them distinctly \\
\hline 16 & The student expresses his ideas in logical and creative ways. \\
\hline B & $\begin{array}{l}\text { Development competencies (linguistic intelligence)To develop the teacher } \\
\text { students characteristics of linguistic intelligence in the following : }\end{array}$ \\
\hline 1 & The teacher increase the words games and stories \\
\hline 2 & $\begin{array}{l}\text { The teacher provides activities based on photo description and comments on } \\
\text { these photos }\end{array}$ \\
\hline 3 & Training in students' communication skills \\
\hline 4 & The teacher engages students in public speaking and debate groups \\
\hline 5 & The teacher conducts seminars between the students \\
\hline 6 & The teacher allows students to express themselves using language \\
\hline 7 & Teacher urges students to undertake group activities \\
\hline 8 & Train the teacher on leadership, planning and motivating others \\
\hline 9 & $\begin{array}{l}\text { The teacher develops the students negotiate, resolve conflicts skills and dealing } \\
\text { with others }\end{array}$ \\
\hline $\mathrm{C}$ & $\begin{array}{l}\text { Enrichment competencies (linguistic intelligence) The teacher provides students } \\
\text { with enrichment linguistic intelligences methods for the following : }\end{array}$ \\
\hline 1 & The teacher allows students to share ideas about the lesson \\
\hline 2 & Teacher helps students to write stories, articles \\
\hline 3 & $\begin{array}{l}\text { The teacher uses voice recorder in classroom lessons to show their linguistic } \\
\text { abilities }\end{array}$ \\
\hline 4 & Teacher urges students to write their notes and interests in a daily record \\
\hline 5 & Teacher provides students with more synonyms per word \\
\hline 6 & $\begin{array}{l}\text { Teacher instructs students to write sentences or short situation using new } \\
\text { vocabulary }\end{array}$ \\
\hline 7 & $\begin{array}{l}\text { The teacher shows the students the preferred way to memorize, which is to speak } \\
\text { and reiterate loudly }\end{array}$ \\
\hline 8 & The teacher organizes the students' councils with the help of experts \\
\hline 9 & $\begin{array}{l}\text { Teacher trains students to use dictionary and lexicon to identify the meanings of } \\
\text { new words, derivatives and synonyms, and spelling }\end{array}$ \\
\hline 10 & The teacher asks students to write expressive topics \\
\hline $\mathrm{D}$ & Assessment competencies (linguistic intelligence) \\
\hline 1 & $\begin{array}{l}\text { To remained the teacher with the tools and bases of linguistic intelligence } \\
\text { assessment }\end{array}$ \\
\hline
\end{tabular}


INTERNATIONAL JOURNAL OF ACADEMIC RESEARCH IN BUSINESS AND SOCIAL SCIENCES Vol. 10, No. 2, Feb, 2020, E-ISSN: 2222-6990 @ 2020 HRMARS

\begin{tabular}{|l|l|}
\hline 2 & $\begin{array}{l}\text { to remind the teacher the characteristics of some of the standards measured to } \\
\text { the assessment of linguistic intelligence }\end{array}$ \\
\hline 3 & The teacher uses some tests to measure linguistic intelligence \\
\hline 4 & $\begin{array}{l}\text { The teacher designs models to measure linguistic intelligence } \\
\text { intelligence }\end{array}$ \\
\hline 5 & \begin{tabular}{l} 
Theacher designs stations and student activities to measure linguistic \\
\hline
\end{tabular} \\
\hline
\end{tabular}


INTERNATIONAL JOURNAL OF ACADEMIC RESEARCH IN BUSINESS AND SOCIAL SCIENCES Vol. 10, No. 2, Feb, 2020, E-ISSN: 2222-6990 (C) 2020 HRMARS

\section{Annex (3) \\ Special competencies must be reached by the teacher (Social Intelligence)}

\begin{tabular}{|c|c|}
\hline (A) & $\begin{array}{l}\text { Identification competencies (social intelligence)The teacher should distinguish } \\
\text { the following characteristics of social intelligence among his students }\end{array}$ \\
\hline 1 & student interest in communicating with peers \\
\hline 2 & Student offers tips to friends as leader \\
\hline 3 & dealing with other students in high competencies \\
\hline 4 & help others directly and indirectly \\
\hline 5 & Ensure that students form friendships \\
\hline 6 & Students should be interested in joining groups and clubs with peers \\
\hline 7 & focused on the student's ability to understand others \\
\hline 8 & showing student curiosity towards others \\
\hline 9 & Use the student gut instinct in making decisions \\
\hline 10 & The student's ability to understand and control his feelings \\
\hline 11 & Pursuit always for the development of his character \\
\hline (B) & $\begin{array}{l}\text { development competencies (social intelligence); The teacher develops the } \\
\text { following social intelligence characteristics in }\end{array}$ \\
\hline 1 & his students \\
\hline 2 & Teacher gives students a leadership role at some times \\
\hline 3 & $\begin{array}{l}\text { The teacher develops the skills of negotiation, conflict resolution and dealing } \\
\text { with others in his students. }\end{array}$ \\
\hline 4 & Teacher trains students to plan activities and motivate others \\
\hline 5 & Teacher trains students to hold alms and preserve them \\
\hline 6 & The teacher urges the students to undertake collective voluntary activities \\
\hline 7 & Teachers alert students not to shout while talking, but rather to remain calm \\
\hline 8 & $\begin{array}{l}\text { Teacher trains students to stay away from sensitivity, especially in the case of } \\
\text { criticism }\end{array}$ \\
\hline 9 & $\begin{array}{l}\text { The teacher encourages the students to speak openly, taking into account the } \\
\text { feelings of others }\end{array}$ \\
\hline (C) & $\begin{array}{l}\text { Enrichment competencies (social intelligence)To practice the teacher methods } \\
\text { of enriching the following social intelligence with his students }\end{array}$ \\
\hline 1 & The teacher points students to share their work with their colleagues \\
\hline 2 & $\begin{array}{l}\text { The teacher organizes small work groups for the students in the class to handle } \\
\text { learning tasks in different ways }\end{array}$ \\
\hline 3 & The teacher creates multiplayer games within the class \\
\hline 4 & Teacher encourages students to participate in creating some idea collectively \\
\hline 5 & $\begin{array}{l}\text { The teacher directs the students towards maintaining the integrity of the school } \\
\text { property }\end{array}$ \\
\hline 6 & teacher train the students to solve simple problems \\
\hline 7 & Teachers encouraged students to express their views freely and reassuringly. \\
\hline
\end{tabular}


INTERNATIONAL JOURNAL OF ACADEMIC RESEARCH IN BUSINESS AND SOCIAL SCIENCES Vol. 10, No. 2, Feb, 2020, E-ISSN: 2222-6990 @ 2020 HRMARS

\begin{tabular}{|l|l|}
\hline (C) & $\begin{array}{l}\text { Assessment competencies (social intelligence) The teacher distinguishes the } \\
\text { social intelligence assessment tools. }\end{array}$ \\
\hline 1 & $\begin{array}{l}\text { that the teacher uses some standardized measures to measure social } \\
\text { intelligence }\end{array}$ \\
\hline 2 & that the teacher uses some tests to measure social intelligence \\
\hline 3 & that the teacher design models to measure social intelligence \\
\hline 4 & $\begin{array}{l}\text { The teacher should design student attitudes and activities to measure social } \\
\text { intelligence }\end{array}$ \\
\hline 5 & $\begin{array}{l}\text { The teacher should design models for performance cards to measure social } \\
\text { intelligence skills }\end{array}$ \\
\hline
\end{tabular}

\section{Annex (4)}

Special competencies must be reached by the teacher (Mathematical intelligence)

\begin{tabular}{|c|c|}
\hline (A) & $\begin{array}{l}\text { identification competence (mathematical intelligence) The teacher should } \\
\text { distinguish the following mathematical logical intelligence skills }\end{array}$ \\
\hline 1 & The student asks many questions about how to use things \\
\hline 2 & The student enjoys classes that have mathematical questions \\
\hline 3 & The student work done by hands \\
\hline 4 & The student likes to classes that have scientific experiments \\
\hline 5 & The student should is interested with subjects related to science \\
\hline 6 & The student plays strategical and logical games such as chess \\
\hline 7 & $\begin{array}{l}\text { The student should exercise the ability to categorize, infer, generalize and } \\
\text { test hypotheses. }\end{array}$ \\
\hline 8 & $\begin{array}{l}\text { The student distinguishes things according to patterns, relationships, } \\
\text { sequence and logic }\end{array}$ \\
\hline 9 & The student shows the ability to solve the puzzles \\
\hline 10 & The student shows skill in discovering cause and effect \\
\hline 11 & The student shows the ability to calculate distances \\
\hline (B) & $\begin{array}{l}\text { Development competence (mathematical intelligence) The teacher } \\
\text { develops the following linguistic intelligence characteristics of his students: }\end{array}$ \\
\hline 1 & The teacher gives students daily mobile activities \\
\hline 2 & The teacher organizes students' sports competitions such as chess \\
\hline 3 & The teacher helps students deal with information in an applied way \\
\hline 4 & $\begin{array}{l}\text { The teacher Instructs students to use the computer to learn to understand } \\
\text { some concepts }\end{array}$ \\
\hline 5 & $\begin{array}{l}\text { The teacher helps students to visit scientific museums, exhibitions of } \\
\text { discoveries and inventions }\end{array}$ \\
\hline (C) & $\begin{array}{l}\text { Enrichment competence (mathematical intelligence) The teacher enriches } \\
\text { the logical intelligence methods of his students in the following ways }\end{array}$ \\
\hline 1 & The teacher encourages students to use numbers and calculate quantities \\
\hline
\end{tabular}


INTERNATIONAL JOURNAL OF ACADEMIC RESEARCH IN BUSINESS AND SOCIAL SCIENCES Vol. 10, No. 2, Feb, 2020, E-ISSN: 2222-6990 @ 2020 HRMARS

\begin{tabular}{|c|c|}
\hline 2 & The teacher trains students to classify things into categories \\
\hline 3 & $\begin{array}{l}\text { The teacher encourages students to participate in sports activities inside or } \\
\text { outside the school }\end{array}$ \\
\hline 4 & $\begin{array}{l}\text { The teacher enriches students' skills of comparison and self-discovery of the } \\
\text { problem and how to search for a solution }\end{array}$ \\
\hline 5 & $\begin{array}{l}\text { The teacher motivates students to use scientific ideas to understand some } \\
\text { phenomena }\end{array}$ \\
\hline (D) & $\begin{array}{l}\text { Assessment competence (mathematical intelligence) The teacher should } \\
\text { distinguish the following mathematical assessment tools for his students }\end{array}$ \\
\hline 1 & $\begin{array}{l}\text { The teacher uses some standardized measures to measure mathematical } \\
\text { intelligence. }\end{array}$ \\
\hline 2 & The teacher uses some tests to measure mathematical intelligence \\
\hline 3 & The teacher design models to measure mathematical intelligence \\
\hline 4 & $\begin{array}{l}\text { The teacher should design student attitudes and activities to measure } \\
\text { mathematical intelligence. }\end{array}$ \\
\hline 5 & $\begin{array}{l}\text { The teacher should design models for performance cards to measure the } \\
\text { skills of mathematical intelligence. }\end{array}$ \\
\hline
\end{tabular}

